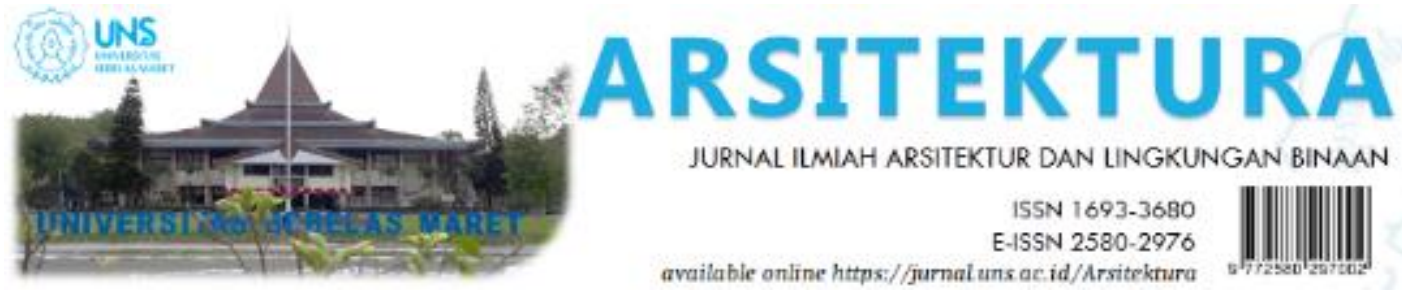

Volume 19 Issue 2 October 2021, pages:205-216

\title{
Kajian Signage dan Elemen Wayfinding di Kampus Perguruan Tinggi (Studi Kasus : Kampus ITS Surabaya)
}

\section{Study of Signage and Wayfinding in University Campus Case Study : ITS Campus Surabaya, Indonesia}

\author{
Vippy Dharmawan ${ }^{1 *}$, Nanik Rachmaniyah ${ }^{2}$ \\ Department Architecture, Muhammadiyah University of Surabaya ${ }^{1 *}$ \\ Vippy.dharmawan@ft.um-surabaya.ac.id \\ Department Interior, Institut Teknologi 10 Nopember Surabaya ${ }^{2}$
}

DOI: https://doi.org/10.20961/arst.v19i2.49152

Received: March 07, 2021 Revised: May 06, 2021 Accepted: May 10, 2021 Available online: October 30, 2021

\begin{abstract}
A wide university campus which consist of many buildings need a good signage and wayfinding system arrangement. Meanwhile, the development of campus buildings is not necessarily accompanied by integrated wayfinding system planning. This article explain the finding of study on signage and wayfinding system on ITS Campus in Surabaya. The purpose of this study is to find out how signages and elements of the area work in wayfinding system on the campus. This qualitative descriptive study used direct observation in collecting data in the field. The result shows that generally the wayfinding system on the campus has been well implemented. However, it needs to optimize the signages that already available so that wayfinding activity can be carried out more easily by people who have not been familiar with the campus area.
\end{abstract}

Keywords: campus; signage; wayfinding

\section{PENDAHULUAN}

Kampus perguruan tinggi di Indonesia, terutama perguruan tinggi negeri terkemuka, biasanya dibangun di tanah yang relatif cukup luas. Misalnya kampus Universitas Indonesia di Depok Jawa Barat, kampus Universitas Diponegoro di Semarang, kampus Universitas Hasanuddin di Makassar, dan tak ketinggalan kampus Institut Teknologi Sepuluh Nopember atau ITS di kota Surabaya. Selain ITS terdapat juga 2 perguruan tinggi negeri lain di Surabaya, yaitu UNAIR dan UINSA, yang juga menempati areal tanah yang cukup luas. Kampus ITS sendiri menempati area tanah seluas kurang lebih 150 Ha dengan puluhan unit bangunan yang luas keseluruhan lantainya kurang lebih $15.000 \mathrm{~m} 2$. Posisi gedung fakultas, departemen, dan gedung-gedung fasilitas penunjang yang terpisah-pisah menuntut adanya sistem wayfinding yang baik agar pengunjung, mahasiswa, maupun staf akademik mudah melakukan orientasi dan mencari arah di dalam kampus tersebut.

Sementara itu di sisi lain pengembangan sebuah kampus belum tentu disertai dengan perencanaan sistem wayfinding yang terintegrasi. Hal seperti ini banyak dialami kampus-kampus perguruan tinggi di Indonesia. 
Penyebab utamanya adalah karena kampus tersebut dibangun secara bertahap, disesuaikan dengan ketersediaan anggaran pembangunan. Bangunan dan fasilitas kampus dibangun satu demi satu sesuai dengan masterplan atau rencana pengembangan yang ada. Padahal kebanyakan masterplan belum mempertimbangkan secara rinci sistem wayfinding pada kampus tersebut nantinya.

Hal tersebut dapat dijumpai di kampus ITS atau Institut Teknologi Sepuluh Nopember, salah satu perguruan tinggi negeri terkemuka di kota Surabaya. Gedung dan fasilitas yang ada di kampus ini dibangun secara bertahap sesuai dengan perkembangan ITS yang ditandai dengan bertambahnya fakultas dan departemen atau program studi. Sejalan dengan itu jumlah mahasiswa juga bertambah, dan saat ini ITS terus menambah gedung dan fasilitas lainnya untuk memenuhi kebutuhannya. Pengamatan awal menunjukkan bahwa sistem wayfinding di kampus ini masih perlu disempurnakan. Diindikasikan dengan adanya kebingungan bagi pengunjung yang baru pertamakali ke kampus ini dalam mengenal tempat dan menentukan arah.

Wayfinding sendiri secara sederhana dapat diartikan sebagai proses seseorang mengenal posisi dimana ia berada di suatu tempat dan menentukan arah tempat yang akan dituju. Ada banyak definisi dan pengertian tentang wayfinding. Menurut Hunter wayfinding adalah proses pengumpulan informasi dan pengambilan keputusan yang dilakukan orang untuk mengarahkan diri mereka bergerak melalui ruang atau berpindah dari satu tempat ke tempat lainnya (Hunter, 2010). Sementara Passini mendefiniskan wayfinding sebagai kemampuan untuk menemukan jalan menuju suatu lokasi (Passini, 1984). Pendapat lain mengatakan bahwa wayfinding merupakan proses seseorang menentukan dan mengikuti suatu rute antara titik asal dengan titik tujuan (Golledge, 1999).

Banyak penelitian tentang wayfinding yang didasarkan pada studi yang dilakukan oleh ahli teori urban asal Amerika, Kevin Lynch, yang ditulis dalam bukunya 'The Image of The City pada tahun 1960. Studi ini dilakukan Lynch selama 5 tahun di Boston, Jersey City dan Los Angeles. Tujuannya untuk mengetahui bagaimana pengamat mengambil informasi kota dan menggunakannya untuk membuat peta mental. Ia menyimpulkan bahwa seseorang membentuk peta mental dari informasi elemenelemen lingkungan di sekitarnya yang terdiri dari 5 elemen dasar. Yaitu path, edge, district, node, dan landmark (Lynch, 1960). Pengertian peta mental disini adalah peta kognitif yang sering digunakan dalam bidang psikologi (Schenk, 2013 hlm 2).

Path adalah jalan atau jejalur. Ia adalah elemen linier berupa jalan, trotoar, jalur kereta api, sungai, dll. Fungsi utamanya adalah sebagai jalur sirkulasi yang umum dilalui orang, barang, atau kendaraan. Elemen path kadang membentuk pola-pola tertentu, kadang juga tidak beraturan. Kebanyakan orang mudah mengenali elemen ini dan menyimpan di memorinya, baik secara sadar ataupun tidak karena jalur-jalur ini cukup sering dilalui dalam kehidupan sehari-hari. Menurut Lynch, Path adalah elemen yang paling penting dalam membentuk gambaran atau citra sebuah kota.

Sama dengan path, edge atau tepian juga berupa elemen linier. Namun ia tidak digunakan atau dianggap sebagai path. Ia tidak digunakan sebagai jalur sirkulasi. Ia lebih cenderung berfungsi sebagai batas dua wilayah. Berbeda dengan path dimana pengamat mempersepsikannya sebagai ði dalam maupun di luar dirinya, edge dipersepsikan oleh pengamat berada di luar dirinya. Termasuk dalam edge adalah : pagar, jalur tanaman semak, deretan pepohonan, tepian bangunan, tepian pantai dan lain-lain. Sering juga elemen path juga sekaligus berperan sebagai edge. Misalnya jalan yang melingkari suatu taman kota. Ia merupakan edge dari taman tersebut. Edge bisa berupa hal yang nyata seperti pagar pembatas, deretan fasad bangunan, atau bisa juga sesuatu yang dipersepsikan sebagai batas atau tepian.

District atau distrik adalah suatu kawasan atau area dalam skala kota dimana manusia merasakan 'masuk' dan 'keluar' dari kawasan tersebut yang disebabkan oleh perbedaan karakter secara umum. Distrik disini bukanlah wilayah administratif, namun lebih ke suasana dan karakter visual yang dirasakan oleh manusia. Distrik biasanya memiliki karakteristik elemen fisik yang homogen. 
Elemen fisik ini kemudian menjadi penciri yang mudah dikenal dan menjadi karakter kawasan tersebut. Misalnya lebar jalan, gaya arsitektur bangunan, pepohonan, dan sebagainya. Kawasan pusat kota di kota metropolitan seperti Jakarta misalnya, ditandai dengan keberadaan bangunan-bangunan tinggi yang berdiri rapat di tepi jalan-jalan yang lebar.

Selanjutnya Node adalah titik penting atau strategis dalam sebuah kota. Oleh karena itu sebaiknya lokasi area informasi harus ditempatkan di titik ini (Hantari \& Ikaputra, 2020). Node kebanyakan terbentuk dari simpul atau persilangan path seperti persimpangan jalan atau pertemuan dua buah jalan. Juga bisa berupa perhentian, ruang terbuka, pasar, stasiun, bandara, taman kota, atau titik-titik lain dimana seseorang menjadikannya sebagai titik tempat dimana dia berangkat atau sampai. Elemen node yang karakternya kuat dapat menandai keberadaan suatu distrik. Walaupun begitu, tidak setiap persimpangan jalan adalah node. Tergantung citra place terhadap persimpangan tersebut. Ia harus punya karakter atau identitas yang mudah diingat agar dapat menjadi suatu node.

Elemen yang terakhir yang membentuk peta mental menurut Lynch adalah landmark. Elemen ini sangat mudah dikenali karena karakternya yang sangat kuat dan mudah diingat serta dikenali. Ia menjadi penanda dan titik acuan bagi seseorang dalam melakukan wayfinding. Landmark biasanya dikenali dari bentuk fisiknya yang dominan. Baik dominan karena ukuran dan bentuk, maupun ciri-ciri visual lainnya. Suatu obyek yang jauh lebih besar dari obyek-obyek lain di sekitarnya akan nampak dominan. Demikian juga obyek yang mempunyai bentuk atau ciri visual yang beda dengan obyek di sekitarnya juga akan nampak dominan dan berkarakter kuat.

Selain 5 elemen yang disebutkan Lynch tersebut, terdapat juga elemen lain yang juga mempengaruhi proses wayfinding, yaitu signage. Secara umum signage atau penanda diartikan sebagai sesuatu yang digunakan untuk memberikan tanda atau petunjuk. Biasanya berbentuk susunan huruf yang dituliskan pada sebuah papan atau lempengan untuk memberikan informasi, peringatan, larangan, atau petunjuk untuk mengarahkan seseorang menuju sesuatu. Kadang juga berbentuk tugu nama yang terbuat dari konstruksi yang lebih kuat dan kokoh. Keberadaan signage menghadirkan proses pengulangan yang konsisten pada elemen visual seperti bentuk, garis, atau warna yang disajikan olehnya. Ini menjadikan signage sebagai bagian dari identitas atau brand image suatu kawasan (Ischak et al., 2018).

Ada banyak jenis signage. Dari segi fungsi atau tujuan pembuatannya, signage dapat dikategorikan menjadi 4 macam. Signage identitas, signage penunjuk arah, signage informasi, dan signage himbauan dan larangan. Biasanya desain signage disesuaikan dengan fungsinya tersebut. Menurut Shirvani signage harus dapat menggambarkan karakter dan ide dari suatu kawasan. Selain itu jarak penempatan penanda harus efektif untuk menghindari kekacauan visual dan keambiguan dalam informasi yang diberikan (Shirvani, 1985). Desain signage selain mementingkan keindahan, juga harus memiliki ketinggian, tipografi, material, warna, bentuk dan posisi yang sesuai dengan kebutuhan agar fungsinya dapat optimal (Dewi et al., 2019).

Penelitian-penelitian terdahulu tidak banyak yang mengambil obyek kampus pendidikan tinggi (Febriyantoko, 2019) (Natalisa, 2014) (Andrivina, 2019) . Sementara di Indonesia hanya sedikit kompleks bangunan pendidikan yang dibangun sekaligus, lengkap dengan seluruh fasilitas yang ada di dalamnya, sehingga aspek sistem wayfinding cenderung terabaikan. Studi terbaru dilakukan oleh Minggra di kampus Universitas Pendidikan Indonesia (UPI) pada tahun 2020 lalu. Studi ini mengevaluasi signage yang terdapat di kampus ini sebagai bagian dari sistem wayfinding. Salah satu hasil studi mengungkapkan bahwa signage identitas di dalam kawasan kampus yang tidak seragam mengganggu kemampuan orang dalam proses penemuan jalan di dalam kawasan kampus tersebut. Ketidak seragaman yang terjadi pada aplikasi warna, aplikasi jenis huruf, dan aplikasi material pada penandapenanda identitas di dalam satu kawasan yang tidak sama akan meningkatkan keraguan terhadap keputusan dan rencana yang diambil pada proses penemuan tujuan (Minggra, 2020). 
Penelitian yang dilakukan di kampus ITS ini bertujuan untuk mengetahui sejauh mana elemen-elemen lingkungan fisik berpengaruh pada system wayfinding yang ada di kompleks bangunan pendidikan yang umumnya dibangun secara bertahap, seperti halnya penelitian sebelumnya yang dilakukan di kampus UPI. Hanya saja penelitian ini dilakukan dalam lingkup yang lebih luas, tidak hanya mencakup system signage saja. Namun juga elemen lainnya yang meliputi bangunan dan prasarana fisik seperti jalan, pepohonan, dan ruang terbuka.

\section{METODE}

Penelitian dilakukan dengan pendekatan deskriptif kualitatif dengan cara mendeskripsikan dan mengkategorikan fasilitas signage dan elemen-elemen lingkungan fisik yang menunjang sistem wayfinding di kampus ITS. Pengkategorian elemen fisik didasarkan pada teori tentang citra suatu kota atau kawasan yang dikemukakan oleh Lynch. Hanya saja dalam konteks ini pengkategorian tersebut dilakukan dalam skala lingkungan kampus. Mengacu pada teori tersebut maka elemenelemen yang diamati meliputi elemen district, path, edge, node, dan landmark. Selain itu juga diidentifikasi signage-signage yang berisikan petunjuk arah, identitas, dan lokasi fakultas, program studi, dan tempat-tempat penting lainnya di kampus. Pengumpulan data dilakukan dengan cara observasi atau pengamatan langsung oleh peneliti yang didukung wawancara pada pengguna bangunan dan sarana di kampus ini.

Penelitian diawali dengan mengidentifikasi district atau kawasan-kawasan yang ada di lingkungan kampus. Dilakukan dengan cara berjalan mengelilingi kampus dan merasakan kesan 'keluar' dan 'masuk' area-area yang ada di kawasan kampus. Dalam hal ini peneliti, yang pernah berkunjung namun tidak secara rutin beraktivitas disitu, berperan sebagai pengamat yang belum familiar terhadap situasi kampus. Hal ini dilakukan agar bisa didapatkan pengalaman wayfinding seseorang yang belum pernah berkunjung ke kampus ini. Hasil dari pengamatan secara berkeliling kampus ini adalah berupa identifikasi kawasan-kawasan yang ada di kampus beserta ciri-ciri yang membentuk citranya.
Langkah berikutnya adalah mengamati elemenelemen fisik yang ada pada tiap-tiap kawasan. Pengamatan difokuskan pada elemen yang berada di sekitar jalan-jalan utama kampus. Selain elemen fisik juga diamati signage petunjuk arah, petunjuk lokasi, dan identitas dari bangunan fakultas, departemen, serta bangunan penting lainnya. Selanjutnya masingmasing elemen fisik diberi catatan sejauh mana kontribusinya terhadap terbentuknya gambaran atau citra yang melekat di kawasan tersebut. Aspek dari unsur yang mempengaruhi citra antara lain ukuran, bentuk, warna, dan usnsurunsur visual lainnya. Obyek yang secara visual dominan akan memberikan citra yang kuat terhadap kawasan tersebut. Hasil identifikasi elemen-elemen wayfinding tadi kemudian dianalisa dengan membandingkan kualitas visual elemen antar kawasan.

\section{HASIL DAN PEMBAHASAN}

Kompleks kampus ITS berada di kawasan timur Surabaya. Bagian utara berbatasan dengan kampus Politeknik Perkapalan Negeri Surabaya (PPNS) dan Politeknik Elektronika Surabaya (PENS) serta Jalan Raya ITS. Bagian timur dan barat dengan perumahan. Sedangkan bagian selatan dengan Jalan Keputih. Akses utama berasal dari Jalan Kertajaya Indah dan Jalan Raya ITS , dimana sebelum masuk ke gerbang utama orang akan menjumpai Bundaran Taman Air Mancur Menari yang sekaligus menjadi landmark kampus. Akses kedua adalah dari Jalan Keputih (gambar 1).

Sebelum PPNS dan PENS menjadi lembaga terpisah dengan ITS, terdapat juga akses pintu masuk dari Jalan Raya ITS. Namun dalam perkembangannya, karena pemisahan manajemen PPNS dan PENS dari ITS, akses dari kompleks ITS ke Jalan Raya ITS menjadi tertutup.

Bangunan-bangunan utama yang ada di kompleks kampus ITS antara lain : gedung Rektorat, Kantor Pusat Administrasi (KPA), gedung Research Center atau Pusat Riset, gedung Robotika, gedung Nasdec, gedung Perpustakaan, Masjid Kampus, dan gedung MIPA Tower. Selain itu ada juga fasilitas stadion utama, stadion futsal, gedung olahraga bulutangkis, medical center, dan perumaha dosen dan karyawan. Adapun pola jalan dalam 
komplek kampus terbentuk oleh jalan kembar yang menghubungkan pintu gerbang utama, pintu keputih, dan gedung Robotika yang terletak di bagian paling utara kampus. Jalan utama ini kemudian bercabang ke jalan-jalan kecil menuju fakultas dan gedung-gedung program studi yang ada di kampus ini.

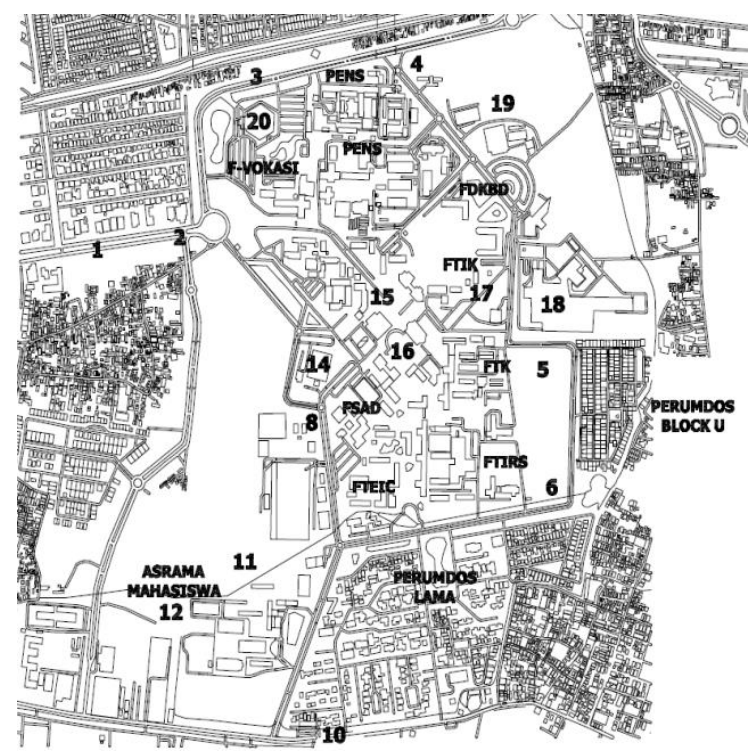

Keterangan :

1. Jl. Raya Kertajaya Indah

2. Bundaran Air Mancur

3. J1. Raya ITS

4. Jl. PPNS-PENS

5. Jl. Teknik Kimia

6. J1. Teknik Perkapalan

7. Jl. Teknik Elektro

8. Jl. Teknik Mesin

9. Jl. Taman Alumni

10.Jl. Keputih

11. GOR Bulutangkis

12. Stadion dan GOR Futsal

13. Menara Sains

14. Masjid Kampus Manarul Ilmi

15. Gedung Rektorat

16. Kantor Pusat Administrasi

17. Research Center

18. Gedung Nasdec

19. Gedung Robotika

20. Gedung Pertemuan Graha ITS

Gambar 1. Kompleks Kampus ITS

\subsection{District dan Landmark}

Terdapat setidaknya sepuluh district atau kawasan di kampus ITS yang dapat dibedakan dari ciri-ciri fisiknya. Yaitu : Taman Air Mancur Menari ITS, Taman Alumni, Rektorat dan Masjid Kampus, Kantor Pusat Administrasi
(KPA), ruas Jalan Teknik Mesin, ruas Jalan Teknik Elektro, ruas Jalan Teknik Perkapalan, ruas Jalan Teknik Kimia segmen 1 dan 2, dan ruas Jalan Raya ITS. Masing-masing kawasan mempunyai ciri fisik dan suasana tersendiri yang membedakan satu kawasan dengan kawasan lainnya. Ada kawasan yang karakter suasananya sangat kuat, ada juga yang biasabiasa saja.

Kawasan Bundaran Taman Air Mancur Menari adalah salah satu kawasan yang menjadi landmark keseluruhan kampus ini, dan menjadi akses utama masuk ke kompleks ITS. Area ini terhubung langsung dengan Jalan Raya Kertajaya Indah yang merupakan salah satu jalan utama di kawasan timur Surabaya. Sebagai pintu utama kompleks kampus ITS, bundaran ini sangat mudah dikenali karena ada taman dan tulisan ITS berukuran besar yang kemudian menjadi landmark kawasan tersebut (gambar 1). Juga karena pola jalan yang melingkar serta material jalan paving yang berbeda dengan jalan di sekitarnya. Orang yang berada di area ini akan segera merasakan bahwa ia telah berada di kompleks kampus ITS. Dari bundaran ini pengunjung masuk ke dalam kompleks melalui pintu gerbang yang ditandai dengan beberapa patung simbolik bambu runcing yang terbuat dari stainless steel. Patung ini menjadi salah satu focal point yang menandai gerbang masuk. Keseluruhan kawasan ini memberikan citra yang kuat dan mudah diingat orang (gambar 3).

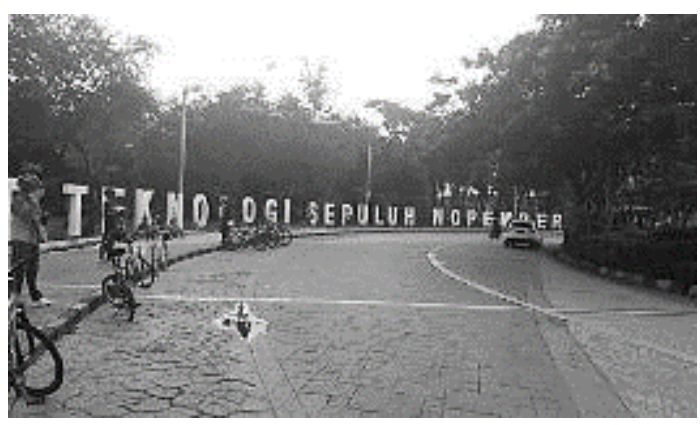

Gambar 2. Tulisan ITS di Bundaran Taman Air Mancur Menari 


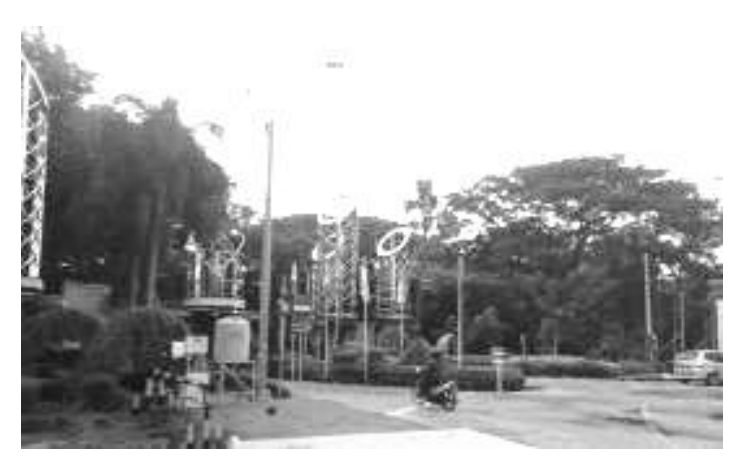

Gambar 3. Patung Bambu Runcing di Pintu Masuk Utama Kompleks ITS

Kawasan lainnya yang juga mempunyai citra yang kuat adalah kawasan taman alumni (gambar 4). Kawasan ini adalah area pertama yang dijumpai orang ketika masuk dari pintu utama ITS. Penanda dari kawasan ini adalah adanya lapangan terbuka yang luas dan mejadi landmark kawasan ini. Keberadaan lapangan ini membuat orang dengan cepat mengetahui bahwa ia berada dekat dengan pintu utama ITS. Selain kedua kawasan tersebut, kawasan Jalan Raya ITS yang terletak di luar pagar kampus ITS juga mempunyai citra yang cukup kuat (gambar 5). Orang yang melewati jalan ini akan sekaligus merasakan suasana ITS dan luar kampus ITS. Suasana ITS dirasakan karena jalan ini berdekatan dengan Bundaran Air Mancur Menari dan juga view ke arah gedung Graha ITS. Sebaliknya suasana luar kampus ITS juga dirasakan karena jalan ini padat dan dilalui oleh beragam kendaraan.

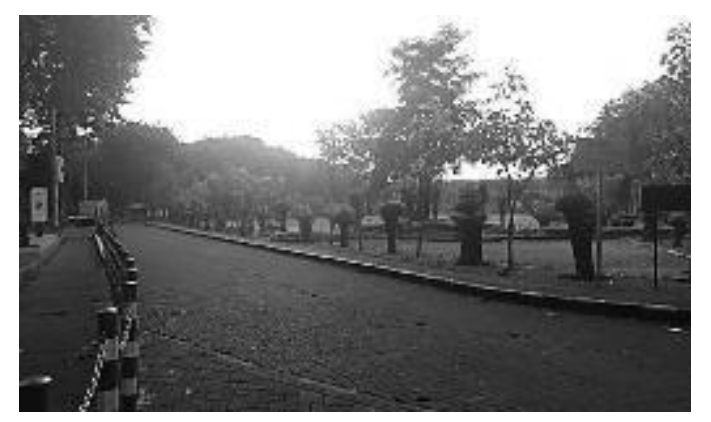

Gambar 4. Taman Alumni

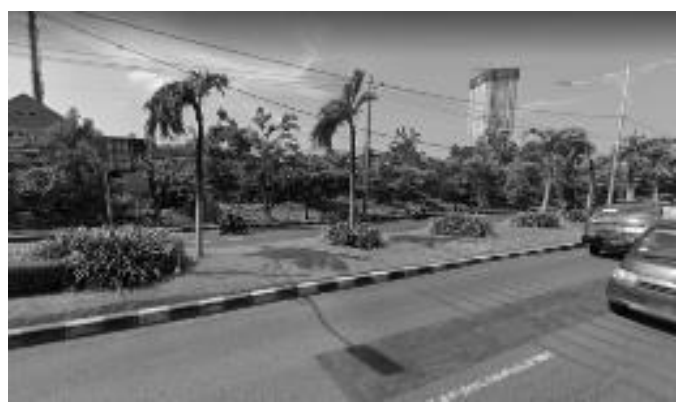

Gambar 5. Taman Alumni

Selain ketiga kawasan tersebut, kawasan lainnya di kompleks ITS juga mempunyai ciriciri atau penanda masing-masing. Walaupun citra yang ditimbulkannya tidaklah terlalu kuat, tapi cukup sebagai unsur pembeda dari kawasan lainnya di kampus ini. Misalnya area rektorat dan masjid dimana terdapat view ke arah gedung rektorat, atau area ruas Jalan Teknik Mesin yang terdapat view ke arah gedung stadion. Tabel 1 menunjukkan bahwa tiap distrik mempunyai elemen-elemen fisik yang khas yang menjadi pembeda kawasan tersebut dengan kawasan lainnya. Elemen-elemen fisik pembeda tersebut dapat membantu pengamat untuk mengenali posisinya di kompleks ITS. Pada sisi lain tabel tersebut juga menunjukkan bahwa terdapat juga elemen fisik berupa pohonpohon dan semak yang sama-sama dimiliki oleh setiap kawasan. Kesamaan tersebut dapat memberi identitas dan citra,yang kuat bagi lingkungan kampus ITS.

Tabel 1. Kualitas Citra District (Kawasan)

\begin{tabular}{|c|c|c|}
\hline $\begin{array}{c}\text { District } \\
\text { (Kawasan) }\end{array}$ & $\begin{array}{c}\text { Eleman yang } \\
\text { Dominan }\end{array}$ & $\begin{array}{c}\text { Kualitas } \\
\text { Citra }\end{array}$ \\
\hline $\begin{array}{l}\text { Bundaran Taman } \\
\text { Air Mancur } \\
\text { Menari }\end{array}$ & $\begin{array}{l}\text { Bundaran } \\
\text { Paving Stone } \\
\text { Huruf ITS }\end{array}$ & Kuat \\
\hline Taman Alumni & $\begin{array}{l}\text { Lapangan } \\
\text { Fasad gedung } \\
\text { dibalik Pohon2 } \\
\end{array}$ & Kuat \\
\hline $\begin{array}{l}\text { Area Rektorat dan } \\
\text { Masjid Kampus }\end{array}$ & $\begin{array}{l}\text { Ged.Rektorat } \\
\text { Fasad gedung } \\
\text { dibalik Pohon2 }\end{array}$ & Sedang \\
\hline $\begin{array}{l}\text { Area Parkir Kan- } \\
\text { tor Pusat Admi- } \\
\text { nistrasi (KPA) }\end{array}$ & $\begin{array}{l}\text { Gedung KPA } \\
\text { Lap. parkir } \\
\text { Fasad gedung } \\
\text { dibalik pohon2 }\end{array}$ & Sedang \\
\hline $\begin{array}{l}\text { Ruas Jalan Teknik } \\
\text { Mesin }\end{array}$ & $\begin{array}{l}\text { Menara Sains } \\
\text { Fasad gedung } \\
\text { dibalik pohon2 }\end{array}$ & Sedang \\
\hline
\end{tabular}


Vippy Dharmawan, Nanik Rachmaniyah, Kajian Signage dan Elemen ...

\begin{tabular}{lll}
\hline $\begin{array}{l}\text { Ruas Jalan Teknik } \\
\text { Elektro }\end{array}$ & $\begin{array}{l}\text { Fasad gedung } \\
\text { dibalik pohon2 }\end{array}$ & Sedang \\
\hline Ruas Jalan Teknik & $\begin{array}{l}\text { Fasad gedung } \\
\text { dibalik pohon2 }\end{array}$ & Sedang \\
Perkapalan & Fasad gedung & Sedang \\
\hline Ruas Jalan Teknik & $\begin{array}{l}\text { Fabalik pohon2 } \\
\text { Kimia (segmen-1) }\end{array}$ & \\
\hline dibas Jalan Teknik & Ged. Robotika & Sedang \\
Kimia (segmen-1) & $\begin{array}{l}\text { Pusat Riset } \\
\text { Fasad gedung }\end{array}$ & \\
& dibalik pohon2 & \\
\hline Ruas Jalan Raya & Jalan Kembar & Kuat \\
ITS & yang lebar & \\
& Lalulintas & \\
& yang padat & \\
\hline
\end{tabular}

\subsection{Path dan Node}

Elemen path atau jalur yang ada di kompleks ITS adalah berupa jalan yang hampir seluruhnya menggunakan bahan paving beton. Terdapat juga trotoar di kanan kiri jalan, serta jalur hijau di tengah jalan (gambar 6). Pada beberapa tempat nampak ada juga jalur hijau yang membatasi trotoar dan jalan raya (gambar 7). Pada area taman alumni dan rektorat trotoar dibuat agak lebar . Jalur hijau selain ditanami rerumputan, juga dilengkapi dengan tanaman semak dan pepohonan.

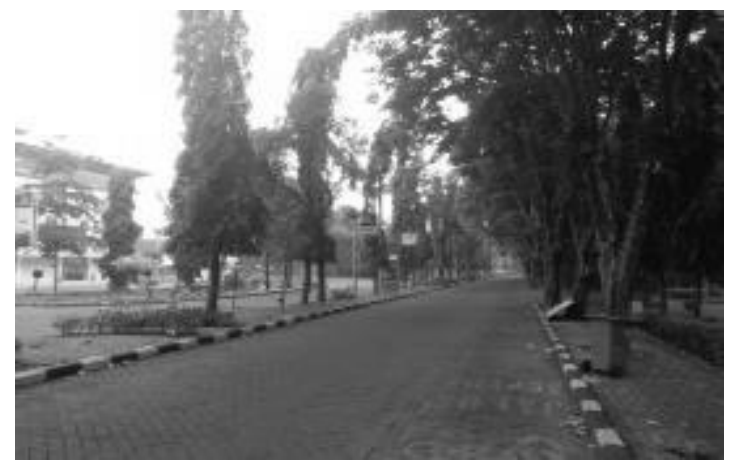

Gambar 6. Jalan Kembar dan Trotoar

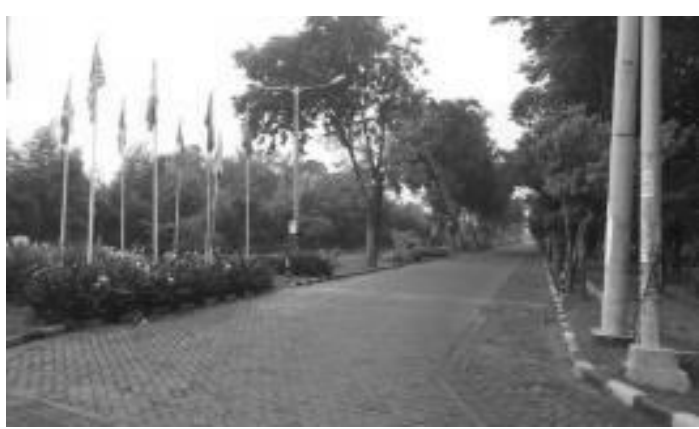

Gambar 7. Jalur Hijau Antara Trotoar dan Jalan
Tabel 2 menunjukkan bentuk dan material jalan-jalan yang ada di kawasan kampus ITS. Kecuali di kawasan Taman Alumni dan Jalan Raya ITS, semua jalan utama di dalam kompleks ITS berupa jalan kembar 2 arah yang di tengahnya ada jalur hijau. Masing-masing sisi jalan terdiri dari 1 jalur kendaraan dan 1 jalur sepeda. Jalan kembar ini menjadi penghubung tempat-tempat penting seperti rektorat, masjid, fakultas-fakultas, stadion, dan fasilitas penunjang lainnya. Pada beberapa tempat jalan ini bercabang ke jalan lebih kecil yang bukan jalan kembar.

Tabel 2. Karakter Path (Jalur/Jalan)

\begin{tabular}{|c|c|c|}
\hline $\begin{array}{c}\text { District } \\
\text { (Kawasan) }\end{array}$ & Elemen Path & Material \\
\hline $\begin{array}{l}\text { Bundaran Taman } \\
\text { Air Mancur } \\
\text { Menari }\end{array}$ & Jalan melingkar & $\begin{array}{l}\text { Paving } \\
\text { stone }\end{array}$ \\
\hline Taman Alumni & $\begin{array}{l}\text { Jalan } 2 \text { lajur } \\
\text { (mobil+sepeda) } \\
\text { searah. } \\
\text { Trotoar }\end{array}$ & $\begin{array}{l}\text { Paving } \\
\text { stone }\end{array}$ \\
\hline $\begin{array}{l}\text { Area Rektorat } \\
\text { dan Masjid } \\
\text { Kampus }\end{array}$ & $\begin{array}{l}\text { Jalan } 2 \text { lajur } \\
\text { (mobil+sepeda) } \\
\text { searah. } \\
\text { Trotoar lebar. }\end{array}$ & $\begin{array}{l}\text { Paving } \\
\text { stone }\end{array}$ \\
\hline $\begin{array}{l}\text { Area Parkir Kan- } \\
\text { tor Pusat Admi- } \\
\text { nistrasi (KPA) }\end{array}$ & - & - \\
\hline $\begin{array}{l}\text { Ruas Jalan } \\
\text { Teknik Mesin }\end{array}$ & $\begin{array}{l}\text { Jalan } 2 \text { lajur } \\
\text { (mobil+sepeda) } \\
2 \text { arah, dibelah } \\
\text { jalur hijau. } \\
\text { Trotoar. }\end{array}$ & $\begin{array}{l}\text { Paving } \\
\text { stone }\end{array}$ \\
\hline $\begin{array}{l}\text { Ruas Jalan } \\
\text { Teknik Elektro }\end{array}$ & $\begin{array}{l}\text { Jalan } 2 \text { lajur } \\
\text { (mobil+sepeda) } \\
2 \text { arah, dibelah } \\
\text { jalur hijau. } \\
\text { Trotoar. }\end{array}$ & $\begin{array}{l}\text { Paving } \\
\text { stone }\end{array}$ \\
\hline $\begin{array}{l}\text { Ruas Jalan } \\
\text { Teknik } \\
\text { Perkapalan }\end{array}$ & $\begin{array}{l}\text { Jalan } 2 \text { lajur } \\
\text { (mobil+sepeda) } \\
2 \text { arah, dibelah } \\
\text { jalur hijau. } \\
\text { Trotoar. }\end{array}$ & $\begin{array}{l}\text { Paving } \\
\text { stone }\end{array}$ \\
\hline $\begin{array}{l}\text { Ruas Jalan } \\
\text { Teknik Kimia } \\
\text { (segmen-1) }\end{array}$ & $\begin{array}{l}\text { Jalan } 2 \text { lajur } \\
\text { (mobil+sepeda) } \\
2 \text { arah, dibelah } \\
\text { jalur hijau. } \\
\text { Trotoar. }\end{array}$ & $\begin{array}{l}\text { Paving } \\
\text { stone }\end{array}$ \\
\hline $\begin{array}{l}\text { Ruas Jalan } \\
\text { Teknik Kimia } \\
\text { (segmen-1) }\end{array}$ & $\begin{array}{l}\text { Jalan } 2 \text { lajur } \\
\text { (mobil+sepeda) } \\
2 \text { arah, dibelah } \\
\text { jalur hijau. }\end{array}$ & $\begin{array}{l}\text { Paving } \\
\text { stone }\end{array}$ \\
\hline
\end{tabular}




\begin{tabular}{lll}
\hline & Trotoar. & \\
\hline Ruas Jalan Raya & Jalan 2 lajur & Aspal \\
ITS & mobil 2 arah.. & \\
\hline
\end{tabular}

Tabel di atas menunjukkan bahwa ruas-ruas jalan di komplek ITS semuanya mempunyai kemiripan karakter, yang dibentuk oleh jalan kembar dan pepohonan yang dominan. Dengan demikian orang dengan mudah dapat merasakan 'suasana' berada dalam kampus ITS. Kecuali jalan di kawasan bundaran taman air mancur dan Jalan Raya ITS yang mempunyai karakter berbeda. Namun perbedaan karakter di Bundaran Taman Air Mancur malah memberikan keuntungan, karena dapat mendukung terciptanya bundaran tersebut menjadi landmark kampus.

Adapun Jalan Raya ITS berada di sisi luar kompleks kampus. Walaupun menggunakan nama ITS, jalan ini digunakan oleh umum dan dikelola oleh pemerintah kota. Jalan ini berupa jalan dua arah yang dipisahkan oleh jalur hijau di tengahnya. Masing-masing sisi jalan terdiri dari dua jalur kendaraan roda empat. Jalan kembar ini menghubungkan Bundaran Taman Air Mancur dengan bundaran yang mengarah ke perumahan Pakuwon City dan Jalan Mulyosari (gambar 1).

Sementara itu elemen node di lingkungan kampus ITS adalah berupa titik-titik persilangan atau pertemuan jalan, bangunan penting, dan ruang terbuka yang menjadi titik awal dan titik tujuan pergerakan orang. Titiktitik tersebut adalah titik yang mudah diingat dan dijadikan acuan dalam aktivitas navigasi orang. Hasil wawancara pada orang yang beraktivitas di kampus menunjukkan titik-titik tersebut adalah sebagai berikut : (1) Bundaran Taman Air Mancur, (2) Area Masjid Kampus gedung Rektorat - gedung Kantor Pusat Administrasi, (3) Pertigaan Bundaran Elektro, (4) Pertigaan Pintu Masuk dari Jalan Keputih, (5) Stadion Kampus, (6) gedung Robotika, (7) gedung Research Center, dan (8) gedung Menara MIPA. Secara keseluruhan dapat dikatakan titik atau node yang ada cukup dapat membantu aktivitas wayfinding.

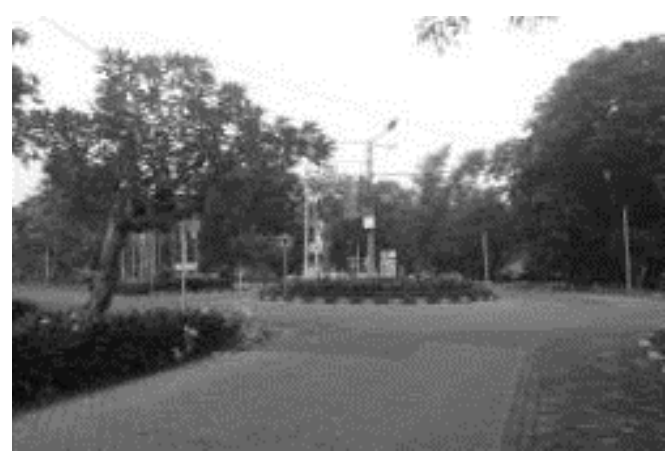

Gambar 8. Bundaran Elektro (salah satu node di kawasan ITS)

\subsection{Edge}

Unsur-unsur yang membentuk edge di kampus ITS antara lain pepohonan, semak, fasad bangunan, signage dengan beragam desain dan ukuran, serta pagar pemisah. Masing-masing unsur mempunyai kualitas citra atau kesan yang berbeda-beda, bergantung pada tampilannya. Misalkan fasad bangunan yang tampil tanpa halangan akan lebih kuat citranya dibandingkan dengan yang fasadnya tertutup sebagian oleh pepohonan. Demikian pula signage yang berukuran besar tentu lebih kuat citranya bila dibandingkan dengan yang lebih kecil. Tampilan edge mempunyai wajah yang beragam. Namun ada kesamaan dan ada perbedaan antara satu kawasan dan kawasan lainnya.

Tabel 3. Karakter Edge (Tepian)

\begin{tabular}{|l|c|c|c|c|c|c|}
\hline \multirow{2}{*}{$\begin{array}{c}\text { District } \\
\text { (Kawasan) }\end{array}$} & \multicolumn{6}{|c|}{ Unsur-unsur Edge } \\
\cline { 2 - 7 } $\begin{array}{l}\text { Bundaran Air } \\
\text { Mancur Menari }\end{array}$ & 1 & 2 & 0 & 3 & 1 & 3 \\
\hline Taman Alumni & 1 & 3 & 3 & 1 & 1 & 3 \\
\hline $\begin{array}{l}\text { Area Rektorat } \\
\text { dan Masjid }\end{array}$ & 1 & 2 & 3 & 2 & 1 & 1 \\
\hline $\begin{array}{l}\text { Area Parkir } \\
\text { KPA }\end{array}$ & 1 & 3 & 2 & 2 & 1 & 2 \\
\hline $\begin{array}{l}\text { Ruas Jalan } \\
\text { Teknik Mesin }\end{array}$ & 1 & 2 & 3 & 2 & 1 & 0 \\
\hline $\begin{array}{l}\text { Ruas Jalan } \\
\text { Teknik Elektro }\end{array}$ & 2 & 1 & 2 & 1 & 1 & 2 \\
\hline $\begin{array}{l}\text { Ruas Jalan Tek- } \\
\text { nik Perkapalan }\end{array}$ & 1 & 2 & 3 & 2 & 1 & 2 \\
\hline $\begin{array}{l}\text { Ruas Jalan } \\
\text { Teknik Kimia 1 }\end{array}$ & 1 & 2 & 2 & 0 & 2 & 3 \\
\hline $\begin{array}{l}\text { Ruas Jalan } \\
\text { Teknik Kimia 2 }\end{array}$ & 3 & 2 & 3 & 2 & 1 & 2 \\
\hline
\end{tabular}




\begin{tabular}{|l|l|l|l|l|l|l|}
\hline $\begin{array}{l}\text { Ruas Jalan } \\
\text { Raya ITS }\end{array}$ & 2 & 2 & 2 & 2 & 2 & 2 \\
\hline
\end{tabular}

Keterangan :
(a) Fasad bangunan
(b) Pohon dan semak
(c) Fasad bangunan di sela pepohonan
(d) Signage identitas
(e) Pagar area
(f) Ruang terbuka 3 - sangat dominan
2 - cukup dominan
1 - kurang dominan

Pada tabel 3 dapat dilihat unsur-unsur yang membentuk edge atau tepian pada tiap-tiap kawasan di ITS. Ada kawasan atau area yang tepiannya sangat didominasi oleh tampilan pohon hingga menutupi bangunan dan unsurunsur lainnya (gambar 9). Yaitu area taman alumni, area rektorat dan masjid kampus, serta area ruas jalan teknik mesin. Ada juga area yang tepiannya didominasi pepohonan namun cukup memberi kesempatan bangunan di belakangnya tampil (gambar 10). Misalnya area ruas jalan teknik elektro, ruas jalan teknik perkapalan, dan ruas jalan teknik kimia. Sementara itu spot-spot tertentu misalnya di depan gedung FTIK, bangunan dapat tampil tanpa halangan. Namun secara keseluruhan edge di kawasan ITS didominasi oleh pohon-pohon.

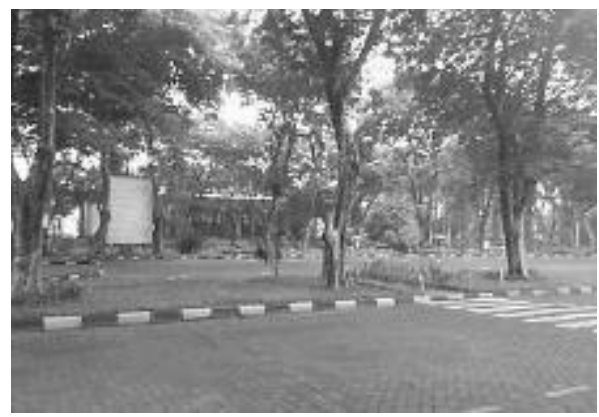

Gambar 9. Masjid Kampus Manarul Ilmi, dengan Fasad di Balik Pepohonan

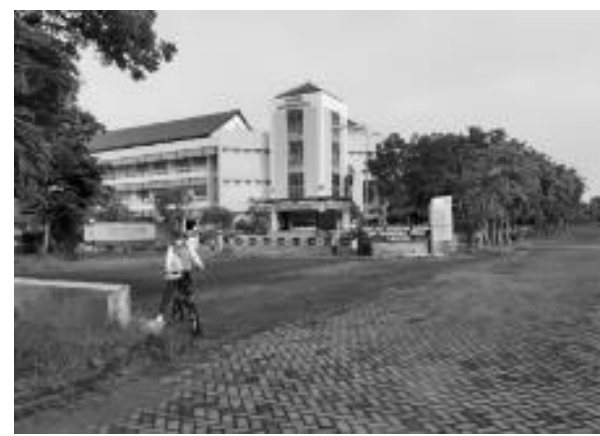

Gambar 10. Pandangan ke Fasad Gedung yang Tidak Terhalangi Pepohonan

Tampilan edge di kawasan kompleks ITS juga ada yang berupa view ke ruang terbuka, seperti lapangan parkir, lapangan rumput, sungai kecil, atau tanah kosong. Beberapa ruang terbuka bahkan dapat berperan sebagai penanda kawasan. Misalnya lapangan di Taman Alumni dan sungai di area FSAD (gambar 11 dan 12).

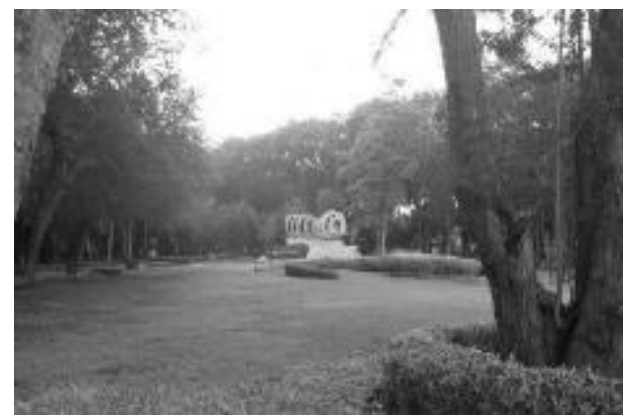

Gambar 11. Taman Eco-Campus

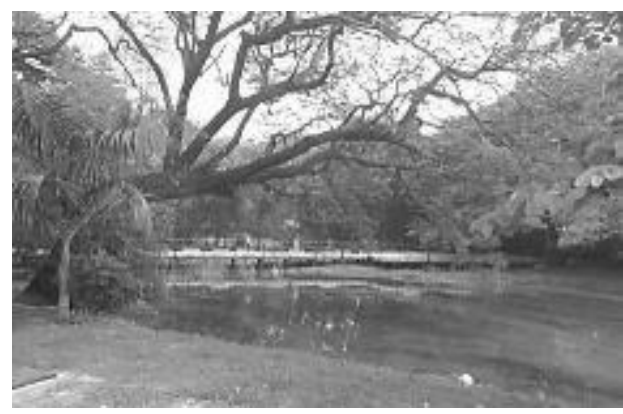

Gambar 12. Sungai Kecil di Area Fakultas FSAD

\subsection{Signage}

Signage atau penanda terkait wayfinding yang ada di kompleks ITS meliputi penanda informasi lokasi, penanda petunjuk arah, dan penanda identitas. Terdiri dari informasi tentang fakultas, departemen atau program studi, dan fasilitas-fasilitas lain seperti rektorat, 
masjid, kantor pusat administrasi (KPA), stadion, gedung pusat riset, dan tempat-tempat penting lainnya. Penanda ini sangat diperlukan, terutama bagi orang yang belum familiar dengan kampus ini, untuk mencari tahu arah dan mengenali tempat yang ditujunya.

Signage/Penanda Informasi Lokasi. Hasil pengamatan menunjukkan bahwa penanda informasi lokasi-lokasi penting dalam lingkup keseluruhan ITS sudah ada, namun masih perlu ditambah dan disempurnakan desainnya. Saat orang masuk dari pintu gerbang utama (arah dari bundaran menara air mancur), mereka belum dapat langsung menjumpai informasi tentang lokasi seluruh tempat-tempat penting di ITS. Hal yang sama juga dialami jika orang masuk dari pintu gerbang kedua, dari arah Jalan Keputih. Informasi lokasi dan fasilitas penting hanya dapat dijumpai di bundaran dekat area parkir KPA dan bundaran Teknik Elektro. Itupun dengan desain dan ukuran yang terlalu kecil untuk dilihat pengamat dari jalan raya. Hal yang berbeda didapatkan ketika orang memasuki area beberapa program studi. Informasi tempat-tempat penting di lingkup program studi nampak sudah cukup tersedia di tempat tersebut dan mudah untuk dilihat oleh pengamat (gambar 13).

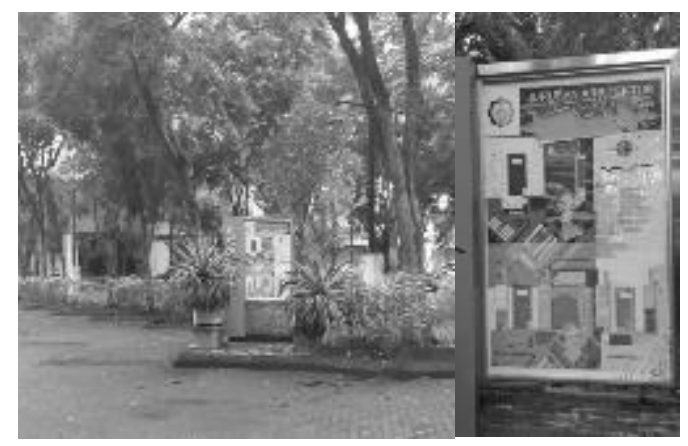

Gambar 13. Signage Informasi Lokasi di Area Departemen/Program Studi

Signage Penunjuk Arah. Sementara itu penanda yang menunjukkan arah fasilitas dan tempat penting cukup memadai, namun kebanyakan dalam ukuran yang tidak cukup besar untuk dilihat dari kejauhan. Walaupun demikian sebagian besar penunjuk arah ke tempat-tempat penting seperti rektorat, fakultas, prodi/departemen sudah ada. Desain papan penanda tersebut juga sudah serupa hingga memudahkan pengunjung yang belum akrab dengan lingkungan kampus (gambar 14).

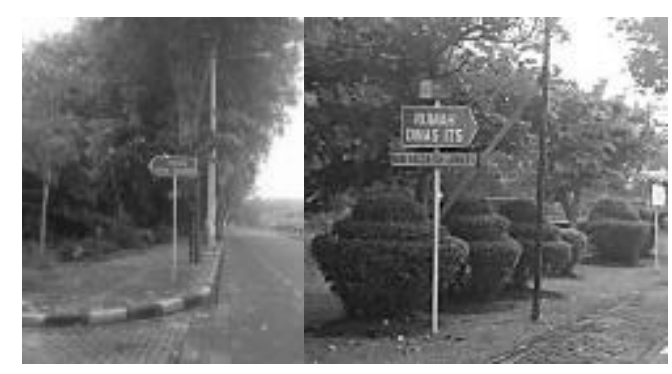

Gambar 14. Signage Penunjuk Arah

Signage/Penanda Identitas. Penanda yang menginformasikan identitas fasilitas atau bangunan juga sudah cukup memadai. Namun demikian tidak semuanya memiliki desain yang serupa. Hanya penanda identitas fakultas yang mempunyai desain serupa antara fakultas yang satu dengan fakultas yang lainnya (gambar 15). Penanda fakultas ini berbentuk kombinasi jajaran genjang yang memanjang ke atas. Tiap fakultas memiliki warna yang berbeda hingga mudah dikenal. Sementara tipe font huruf yang digunakan semuanya sama.

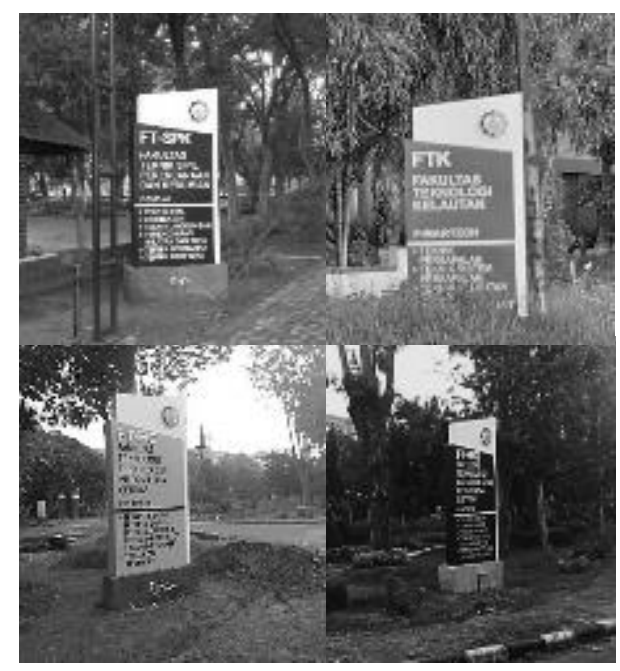

Gambar 15. Signage Identitas Fakultas yang memiliki Desain Serupa

Berlainan dengan yang dimiliki fakultas, penanda identitas milik fasilitas penting dan departemen/prodi mempunyai desain yang berbeda-beda. Baik dalam hal ukuran, bentuk, warna, maupun tipe huruf yang digunakan. Penempatannya pun tidak mengikuti pakem tertentu. Ada yang berada di tepi jalan utama, 
ada yang agak masuk ke dalam, ada pula yang ditempatkan di bagian atas/atap bangunan. Rata-rata penanda identitas prodi tampil dalam ukuran serta desain yang lebih menyolok dibanding penanda fakultas (gambar 16).

Selain itu terdapat juga penanda identitas fakultas versi lama yang belum sempat dibongkar (gambar 17). Dalam kondisi tertentu, penanda ini berpeluang membuat bingung orang yang belum familiar dengan lingkungan kampus ini.

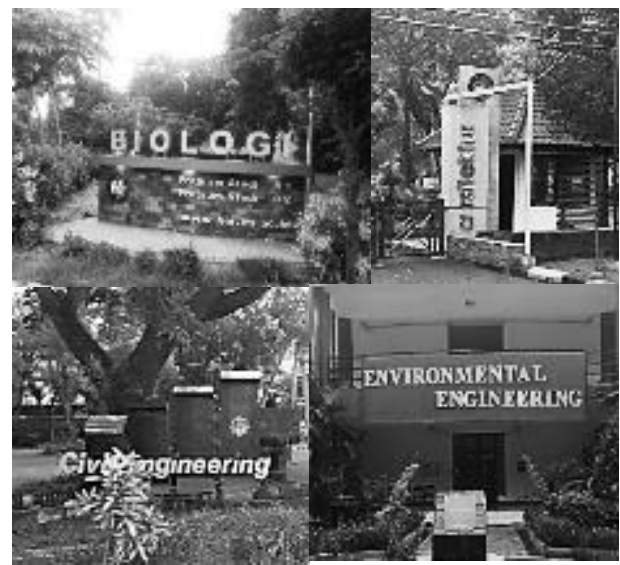

Gambar 16. Signage Identitas Program Studi dengan Desain yang Bervariasi

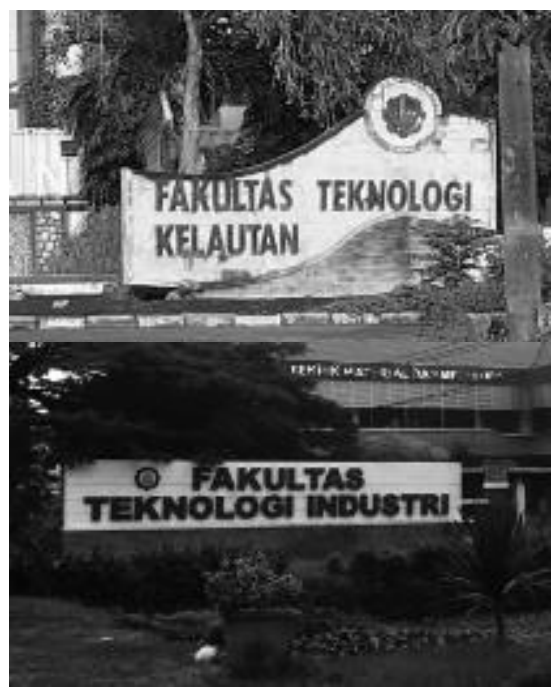

Gambar 17. Signage Identitas Fakultas yang Lama

Secara keseluruhan dibanding elemen fisik lainnya, elemen signage lebih mudah direkayasa untuk meningkatkan kualitas wayfinding. Ini karena biaya untuk mengadakan signage jauh lebih !udah bila dibandingkan dengan membuat atau merenovasi elemen fisik lainnya, seperti jalan atau bangunan. Ada beberapa hal yang bisa dilakukan terhadap sistem signage yang ada. Pertama adalah memperbaiki desain dan menambah jumlah signage informasi lokasi tempat-tempat yang penting. Kedua, memperbesar ukuran signage penunjuk arah. Sedang yang ketiga adalah membuat desain standard signage identitas program studi atau departemen.

\section{KESIMPULAN}

Hasil pengamatan dan kajian yang diuraikan di atas menunjukkan bahwa elemen-elemen fisik dan signage yang ada di kompleks kampus ITS memberi kontribusi yang beragam dalam sistem wayfinding. Ada yang mempunyai peran dominan sebagai pemberi identitas, ada yang dominan dalam menuntun arah, ada juga yang dominan dalam proses berorientasi.

Elemen fisik pepohonan yang tersebar di hampir seluruh kawasan kampus memberi identitas yang kuat pada kampus ini. Pengunjung atau orang yang rutin beraktivitas disini akan segera mengenali suasana kampus begitu menjumpai jalan dan area lainnya yang penuh pepohonan. Selain itu elemen fisik berupa bundaran taman air mancur menari juga memberi identitas yang kuat pada kampus karena desainnya yang unik.

Sementara itu kemudahan orientasi juga didapatkan dengan adanya kekhasan yang dimiliki tiap kawasan di area kampus. Masingmasing memiliki elemen fisik dan suasana berbeda yang ditandai dengan adanya unsurunsur edge yang berbeda-beda pada tiap kawasan. Dengan demikian orang yang sudah familiar dengan kampus ini semisal dosen, mahasiswa, dan karyawan ITS cukup mudah berorientasi dan mencari arah tujuan.

Namun demikian sistem wayfinding masih perlu disempurnakan lagi, terutama bagi orang yang belum familiar dengan kampus ini. Karena semua bagian di kampus ini mempunyai tampilan dominan pepohonan yang hampir serupa. Sementara fasad bangunan dan banyak fasilitas penting pandangannya terhalang oleh pepohonan itu. Aktivitas wayfinding lebih banyak mengandalkan signage informasi 
lokasi. Pada sisi lain terdapat signage yang tidak mudah terlihat, ukurannya terlalu kecil, atau tidak seragam desain dan ukurannya.

\section{REFERENSI}

Andrivina, A. (2019). Persepsi Pengunjung Terhadap Kualitas Wayfinding Sebagai Elemen Interior di Poliklinik RSIA Limijati, Bandung. Jurnal Productum, $3(5)$.

Dewi, C. K. S., Yoedawinata, A., \& Nilotama, S. K. L. (2019). Desain Signage yang Efektif untuk Menghasilkan Wayfinding dan Orientasi Ruang pada Public Space. Jurnal Arsitektur Dimensi, 15(2).

Febriyantoko, D. (2019). Kajian Wayfinding dan Orientasi Ruang Ditinjau dari Aspek Desain Interior Pada Perpustakaan Umum di KotaYogyakarta. Jurnal Lintas Ruang, $7(2)$.

Golledge, R. G. (1999). Wayfinding Behavior, Cognitive Mapping and Other Spatial Processes. John Hopkins Press.

Hantari, A. N., \& Ikaputra. (2020). Wayfinding Dalam Arsitektur. Jurnal Arsitektur Sinektika, 17(2), 96-104.

Hunter, S. (2010). Spatial Orientation, Environmental Perception and wayfinding, Centre for Inclusive Design and Environmental Access. University at Buffalo.

Ischak, M., Setioko, B., \& Gandrum, D. N. (2018). Peran Place Identity dalam Menciptakan Community Resiliance di Wilayah Urban Fringe. Jurnal Arsitektur Zonasi, 1(2).

Lynch, K. (1960). Image of The City. MIT Press.

Minggra, R. (2020). Kajian Penanda Identitas Sebagai Grafis pada Ruang Luar dan Bagian Dari Wayfinding System Kawasan. Jurnal Arsitektur Zonasi, 3(1).

Natalisa, A. (2014). Kriteria Performansi Elemen Wayfinding Pada Bangunan Perbelanjaan [Universitas Jayabaya]. https://osf.io/mshfz

Passini, R. (1984). Wayfinding in Architecture. Van Nostrand Reinhold.

Shirvani, H. (1985). The Urban Design Process. Van Nostrand Reinhold. 